\title{
Age and ICT-Related Behaviours of Higher Education Teachers in Nigeria
}

\author{
Philip Olu Jegede \\ Institute of Education, Obafemi Awolowo University, \\ Ile-Ife, Nigeria
}

pojegede@oauife.edu.ng

\begin{abstract}
The study examined ICT attitude, competence, and use pattern of teacher educators. It also examined the effect of age of educators on time used in interacting with ICT. Four hundred and sixty seven teacher educators from 10 teacher education institutions ( 5 colleges of education and 5 universities) participated in the study. Data were collected with the aid of four research instruments. Resulting data were analyzed using One-way ANOVA and Chi-square statistics. Findings revealed that age is not a factor when considering the attitudes, competence and use pattern of teacher educators. In addition, age was not found to affect the time used on ICT by higher education teachers in Nigeria.
\end{abstract}

Keywords: Age, Behaviour, ICT attitude, use pattern, Nigeria

\section{Introduction}

The impact of new ICT has significantly changed the speed of production, use and distribution of know ledge. Time was when the principal teaching resources available to a professor were the books in the college library, his chalkboard and an occasional map on the classroom. But higher education has exhibited a trend toward a new kind of support for instructional services and an extreme development of facilities to encourage the utilization of new media (Brown and Thornton, 1963). This is made possible through the use of ICT. But a country's capacity to take advantage of the knowledge economy depends on how quickly it can adjust its capacity to generate and share knowledge (Imogie, 2002). There is an apparent consensus that the starting point of this adjustment is with higher education teachers (Aston, 1996; Jegede, 2006; Oliver 1994). This is premised on the fact that opportunity to watch and observe teacher educators teach with ICT is in itself a transfer of skills and behaviour. Oliver (1994) identified the needs for student teachers to experience models of ICT use in their own learning before they can go ahead to implement same in their later profession.

But informal observations reveal that older higher educators are naturally wary of ICT use in

Material published as part of this publication, either on-line or in print, is copy righted by the Informing Science Institute. Permission to make digital or paper copy of part or all of these works for personal or classroom use is granted without fee provided that the copies are not made or distributed for profit or commercial advantage AND that copies 1) bear this notice in full and 2) give the full citation on the first page. It is permissible to abstract these works so long as cred it is given. To copy in all other cases or to republish or to post on a server or to redistribute to lists requires specific permission and payment of a fee. Contact Publisher@InformingScience.org to request redistribution permission. general. The popular saying "you can not teach an old dog new tricks" seem to describe their disposition. If this is so, the situation portends great danger and bleak landscape for poor and nonexistent use of ICT in both primary and secondary schools classrooms. This is because older teacher educators are in most cases the senior teachers occupying professorial chairs. Also the task of 
curriculum design, development and revis ion rest largely on older teacher educators. Their ICT behaviour becomes much more replicated in pre -service teachers than the ICT behaviour of the younger colleagues. Their disposition and skills will no doubt affect their views and perception on how and what ICT training content need be integrated into teacher education curriculum. Apart from this, the effects of age start to become noticeable from the mid-forties onward, so that aging people are not just another minority group but an important segment of the population (Hawthorn, 2000). This is also the case among teacher educators. If situation will improve a starting point is first answering the question what is the influence of age of teacher educators on their ICT behaviour? The reason for starting from this point is because an intervention strategy (if there will be need for any) would require beyond mere speculations and informal observation. Empirical evidences are presently lacking in Nigeria. Thus this study seeks to provide information that will assist in making informed data-based decision regarding ICT-related curricular and instructional matter.

Research results in some developed nations revealed narrowing gaps across age groups in ICT related behaviours. For example Helpguide (2004) found that older Americans are exhibiting better computer behaviour than in the former years. This position finds support in Luchetta (2000) but this narrowing gap across age groups in ICT related behaviour is not a global trend, for example, examining Norway's situation, Hernes, Hestman and Haeland (2000) observed that the share of teachers who state that they have a good command of the use of the Internet is negatively correlated with age. About $77 \%$ of the teachers who are 25 years or younger stated that they have a good command of the use of Internet, compared to $25 \%$ of the teachers who are 56 years or older. Also around $63 \%$ of the teachers who are 25 years or younger versus only $32 \%$ of the teachers who are 56 years or older have a positive attitude towards the use of the Internet in their own teaching. This is also consistent with the findings of Liang and Chao (2002) as they obtained that Taiwan younger teachers were the more literate on Internet.

A different approach entirely was that of William, Wilson, Richardson, Tuson and Coles (2000) as they compared age and ICT attitude of teachers across primary and secondary schools in Scotland. On secondary teachers, clear attitudinal difference was not found across age groups. But amongst primary teachers it appears that rather more of the older respondents have a relatively negative attitude towards ICT. On Canadian teachers, Lam (2000) obtained that age affects the use of ICT in the classroom. It thus seems that the body of literatures yields mixed results. There is the need therefore for research position on this study in Nigeria. Also previous studies (already cited) have investigated age and ICT-related behaviours of teachers in primary and secondary schools; few have carried out this study on teachers of teachers whose behaviours would model that of their trainees. It is on this note that the present study seeks to investigate the influence of age on ICT-related behaviours of teacher educators. The following hypotheses will therefore guide the study

(1) There is no significant difference between the age of higher education teachers and their attitude toward ICT.

(2) There is no significant relationship between the age of higher education teachers and their ICT use pattern.

(3) There is no significant difference between the age of higher education teachers and the time spent on computer.

(4) There is no significant difference between age of higher education teachers and their ICT competence. 


\section{Method}

\section{Participants}

Four hundred and sixty seven higher education teachers (355 male and 112 females; with mean = 42.93 years, $S . D=1.78$ ) selected from 5 universities and 5 colleges of education (totaling 10 institutions) participated in the study, the sample selection made use of stratified random sampling procedure with institutional type as stratification factor. The selected teachers cut across all professional status, subject discipline and age groups.

\section{Measure}

The study made use of four research instruments namely Selwyn-soh ICT Attitudinal Scale, Teacher Educators ICT Competence Scale, ICT Use Checklist and a questionnaire.

Selwyn - Soh scale comprised of 21 five-point Likhert- type item with five subscores -Affective component assess whether the user may have fear, apprehension discomfort or hesitation towards ICT. Perceived usefulness component assesses whether the user finds ICT to enhance work performance. Perceived behaviour assesses whether ICT is used regularly. Perceived control component assesses a person's perceived ability to control computers, Defense component assesses whether a person have a defensive attitude against the use of ICT. The items were scored as Strongly agree $=4$, Agree $=3$, Disagree $=2$, Strongly disagree $=1$, Not sure $=0$. The overall score yields teachers ICT attitude.

The ICT competence scale is also a 21 five point Likert item. Most of the items in this scale were drawn from the computers competence scale developed by the Board of studies of new SouthWales, Australia. Other items were added to adequately represent the skills needed by teachers. The items were scored as Not at all $=1$, Slightly well $=2$, Fairly well $=3$, Well $=4$, Very well $=5$. The ICT Use Checklist of 11 items was organized into four subscores of Data processing, Word processing, Communication and Instruction. Teachers are to indicate how often ICT has been used for a specific purpose in the past three months. The items were scored as Never $=1$, Occasionally $=2$, Sometimes $=3$, Often $=4$ and Very often $=5$. The questionnaire enquires information on teachers' demographic variable and ICT use background.

\section{Procedure}

Four research instruments were administered on the teachers. The data collection lasted for approximately one year owing partly to crisis and closure of some institutions (a feature which sometimes characterized developing nations' educational system). The closed institutions were eventually substituted for others. The data were collected personally by the researcher and other assistants. The assistants include 2 teachers and 2 final year undergraduate students. About 562 set of instruments were administered in all out of which 466 were used for the study. The shortfall was those that were incorrectly filled and those not returned.

\section{Results}

The resulting data were analyzed using Analys is of variance and Chi-square. Tables 1, 2, 3, and 4 show these results. 
Table 1: Age and ICT Attitude

\begin{tabular}{|c|c|c|c|c|c|}
\hline & Sum of squares & Df & Mean square & $\mathrm{F}$ & Sig \\
\hline \multicolumn{6}{|c|}{ ATTITUDE } \\
\hline Between groups & 678.669 & 8 & 84.834 & .291 & .969 \\
\hline Within groups & 1333594.04 & 458 & 291.690 & & \\
\hline Total & 134272.71 & 466 & & & \\
\hline \multicolumn{6}{|c|}{ AFFECTIVE COMPONENT } \\
\hline Between groups & 304.675 & 8 & 38.084 & .796 & .607 \\
\hline Within groups & 21926.507 & 458 & 47.874 & & \\
\hline Total & 22231.182 & 466 & & & \\
\hline \multicolumn{6}{|c|}{ PERCEIVED USEFULNESS } \\
\hline Between groups & 89.931 & 8 & 11.241 & .727 & .667 \\
\hline Within groups & 7077.504 & 458 & 15.453 & & \\
\hline Total & 7167.435 & 466 & & & \\
\hline \multicolumn{6}{|c|}{ PERCEIVED BEHAVIOUR } \\
\hline Between groups & 18.208 & 8 & 2.276 & .120 & .998 \\
\hline Within groups & 8656.743 & 458 & 18.901 & & \\
\hline Total & 8674.951 & 466 & & & \\
\hline \multicolumn{6}{|c|}{ PERCEIVED CONTROL } \\
\hline Between groups & 139.005 & 8 & 17.382 & 1.182 & .308 \\
\hline Within groups & 6737.249 & 458 & 14.710 & & \\
\hline Total & 6876.304 & 466 & & & \\
\hline \multicolumn{6}{|c|}{ DEFENSE COMPONENT } \\
\hline Between groups & 26.978 & 8 & 3.372 & .629 & .754 \\
\hline Within groups & 2456.483 & 458 & 5.363 & & \\
\hline Total & 2483.460 & 466 & & & \\
\hline
\end{tabular}

Table 2: Age and ICT Use Pattern

\begin{tabular}{|l|c|c|c|}
\hline & Chi-square & df & P \\
\hline Data processing & 16.001 & 16 & .452 \\
Word processing & 20.838 & 16 & .185 \\
Communication & 13.516 & 16 & .635 \\
Instruction & 20.324 & 16 & .206 \\
\hline
\end{tabular}

Table 3: Age and Computer Time

\begin{tabular}{|l|c|c|c|c|c|}
\hline & Sum of Squares & df & Mean Square & F & Sig. \\
\hline Between Groups & 1303.702 & 8 & 162.963 & .889 & .525 \\
Within Groups & 83930.264 & 458 & 183.254 & & \\
Total & 85233.966 & 466 & & & \\
\hline
\end{tabular}

Table 4 : Age and ICT Compe tence

\begin{tabular}{|l|l|c|c|c|c|}
\hline & Sum of Squares & df & Mean Square & F & Sig. \\
\hline Between Groups & 4841.381 & 8 & 605.173 & .846 & .563 \\
Within Groups & 327778.38 & 458 & 715.673 & & \\
Total & 332619.76 & 466 & & & \\
\hline
\end{tabular}


In examining the effect of age on ICT attitude of teachers. Participants rated their attitude with the aid of the said Selwyn-Soh ICT scale. The ages of the teachers were categorized into 8 as follows. Less than 25 years old, 25-29, 30-34, 35-39, 40-44, 45-49, 50-54, 55-59 and 60-65. The classification ended at 65 because higher education teachers in Nigeria do retire from service at 65 years of age. Analysis was done using One-way Analysis of Variance. No significant difference was found between the attitude of teachers and their age $(\mathrm{F}(8,458))=.291, \mathrm{P}=.969)$ as shown in table 1 . The hypothesis that age does not significantly affect attitude of teacher educators towards computer was accepted. Further effort was made to examine the effect of age on each of the attitudinal constructs, no significant difference was found between age and each attitudinal constructs of affective, perceived usefulness and perceived behaviour component with $(\mathrm{F}(8,458)=.796, \mathrm{p}=.607), \mathrm{F}(8,458)=.727, \mathrm{p}=.667)$ and $(\mathrm{F}(8,458)=.120, \mathrm{p}=.998)$ respectively. For perceived control factor and defense component, no significant difference was also found with $(\mathrm{F}(8,458)=1.182, \mathrm{p}=.308)$ and $(\mathrm{F}(8,458)=.629, \mathrm{p}=.754)$ respectively.

On the relationship between age and the type of use (use pattern) to which educators put ICT, no significant relationship was found. Age and ICT use of Data processing $\left(\mathrm{x}^{2}=16.001, \mathrm{P}>.05\right)$; Word processing $\left(\mathrm{x}^{2}=20.838, \mathrm{P}>.05\right)$; Communication $\left(\mathrm{x}^{2}=13.516, \mathrm{P}>.05\right)$ and Instruction $\left(\mathrm{x}^{2}=\right.$ $20.324, \mathrm{P}>$.05) (see table 2 ). Thus the hypothesis that age is not significantly related to computer use pattern was accepted.

The time used on computer was not found to be significantly different across age group of educators with $(\mathrm{F}(8,458)=.889, \mathrm{p}=.525)$ indicating also the acceptance of the hypothesis stating no significant difference between age and time spent by teacher educators on the computer.

In determining whether there is significance difference between age and ICT competence, no significant difference was found with $(\mathrm{F}(8,458)=.846, \mathrm{p}=.563)$.In the same vein, study supported the stated hypothesis indicating no significant difference between age and computer competence of teacher educators.

\section{Discussion}

The study has shown no attitudinal difference across age groups. This is similar to what obtained in the findings of William et al (2000) regarding secondary school teachers in Scotland. However William et al (2000) obtained attitudinal variation across a related study carried out by Teo (2008) on Singapore pre-service teachers, no significant difference was found between age and attitude of pre-service teachers. In addition, Teo obtained no significant difference between age and each of attitudinal construct of perceived usefulness, perceived behaviour, perceived control and defense component.

Even though the study and finding of Teo (2008) seem very related to the present one, caution must be taken in comparing them. This is because the mean age of the participants of Teo's study was 24.2 years. In other words, the participants were quite younger than those of the present study and if no KT attitudinal variation was found in his study, it is likely due to the fact that no significant age variation with the participants.

The study also obtained that the type of use to which educators put ICT is not related to age. It would seem that most of the users bordered on Word processing, Data processing, (i.e. result computation) and communication Jegede (2006) observed that $8 \%$ of almost 500 teacher educators who participated in a related study use ICT to teach. Thus in designing intervention strategy that would enable educators use ICT in the classroom no age group should be left behind

Furthermore, the time used working with ICT does not vary with age group. This is perhaps due to the fact that ICT resources are often used for research and research involvement cut across age group among teacher educators. While young educators use ICT for thesis writing and higher de- 
gree programmes old educators in a bid to climb higher professionally use ICT to write and publish papers. This is much more so that many Nigerian universities now insist on substantial percentage of foreign publications before universities lecturers attain professorial cadre. Older educators therefore need Internet interaction s to as to publish internationally. In addition to this, many universities in Nigeria have now adopted e-registrations, e-administration and e-payments which are at least Internet-based thus educators now by compulsory spend time on the net. This time spent on the net had not left adult folk behind.

On ICT competence, the study also found no significant difference across age group; this is opposed to Norway's situation. For example Hernes, Hestman and Haeland (2000) observed that a good command of Internet is negatively correlated with age. But the case is that this finding is old when we consider the fast changing development in ICT and the extent to which ICT has pervaded all facets of live lihood.

Conclusively, this study obtained that in considering ICT use, skills and time spent using ICT devices by teacher educators and in designing training curriculum in ICT in Nigeria for higher education teachers, age is not a factor. It must however be stated that the finding of this study is only applicable to teacher educators, age might be a factor in ICT-related behaviour of other professionals or group of people.

\section{References}

Aston, M. (1996). The British approach to the integration of IT into the curriculum. In Integrating information technology into education. Chapman and Hall, United Kingdom.

Brown, J. W., \& Tho mton J. W. (1963) News in higher education. Washington, DC: National Education Association, Department of Audio Visual Instruction.

Dulude, L. (2000). Usability of interactive voice response systems in real-life tasks performed by old and young women. An unpublished masters degree thes is submitted to Carleton University, USA.

Hawthorn, D. (2000). Possible implications of aging for interface designers. Interacting with Computers, $12,507-528$

Hernes, F., Hestman, M., \& Haaland, E. (2000). Knowledge and competence in ICT among teachers in Norway. Retrieved 20/12/2006 fro m http://www.ifip.or.at/con2000/iceut2000/iceut09-04.pdf

Imogie, A. I. (2002). Moving education forward through ICT in Nigeria in the new millennium. A keynote address delivered at the National Conference of the Nigerian Association for Educational Media and Technology, November 21, 2002, Obafemi Awolowo University, Ile-Ife, Nigeria.

Jegede, P. O. (2006). A study of the predictors of teacher educators' behaviour towards ICT in furtherance Nigeria. Unpublished Doctoral Thesis: Obafemi Awolo wo University, Ile-ife, Nigeria.

Lam, Y. (2000) Technophobia or technophilia? A preliminary look at why second language teachers do or do not use technology in their classrooms. Canadian Modem Language Review, 56(93), 389-420.

Liang, M. T. L., \& Chao, J. Y. G. (2002). Investigating into the Internet literacy of elementary and junior high school teachers in Taiwan. World Transactions on Engineering and Technology Education, 1(1), 129-131.

Luchatta, T. (2000). Gender and computers. Toolbox or toystore? Gender differences and similarities among children, youth and college students concerning computing attitudes and use. Presented at the Spring 2000 Wisconsin Association of Academic Librarians Conference, April 2000.

Oliver R. (1994). Information technology courses in teacher education: the need for integration. Journal of Information Technology for Teacher Education, 3(3), 135-146. 
Williams, D., Coles, L., Richardson, A., Wilson, K., \& Turson, J.(2000). Integrating ICT in professional practices an analysis of teachers' needs based on a survey of primary and secondary teachers in Scottish schools. Journal of Information Technology in Teacher Education, 9(2), 167-82.

\section{Biography}

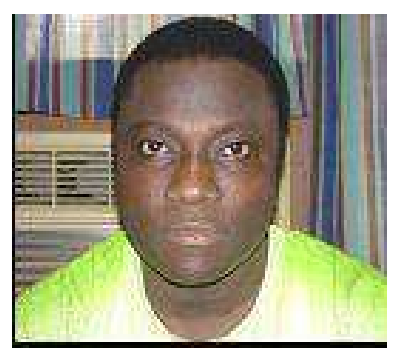

Dr. Philip Jegede is an Associate Professor of ICT Education and Acting Director of the Institute of Education, Obafemi Awolowo University, Ile-Ife, Nigeria. He had B.Sc and M.Sc degrees in Mathematics from the University of Lagos, Nigeria. He later entered into the discipline of Education obtaining M.Ed and Ph.D degrees from the Obafemi Awolowo University, Ile-Ife, Nigeria. His research interest is in ICT Education particularly among pre-service teachers.

He has been a speaker in national and international conferences. His experience in the academics has spanned almost two decades. Before his present appointment he had lectured in a College of Education and a Polytechnic School. 